\title{
大和川流域における河川水の水質特性について CHARACTERISTIC OF RIVER WATER CHEMISTRY IN THE YAMATOGAWA BASIN
}

\author{
窪原拓馬 1 -井伊博行 $2 \cdot$ 平田健正 $3 \cdot$ 江種伸之 $4 \cdot$ 石塚正秀 $5 \cdot$ 伊勢達男 6 •宮川勇二 6 \\ Takuma KUBOHARA, Hiroyuki II, Tatemasa HIRATA, Nobuyuki EGUSA, Masahide ISHIZUKA, \\ Tatsuo ISE and Yuji MIYAGAWA

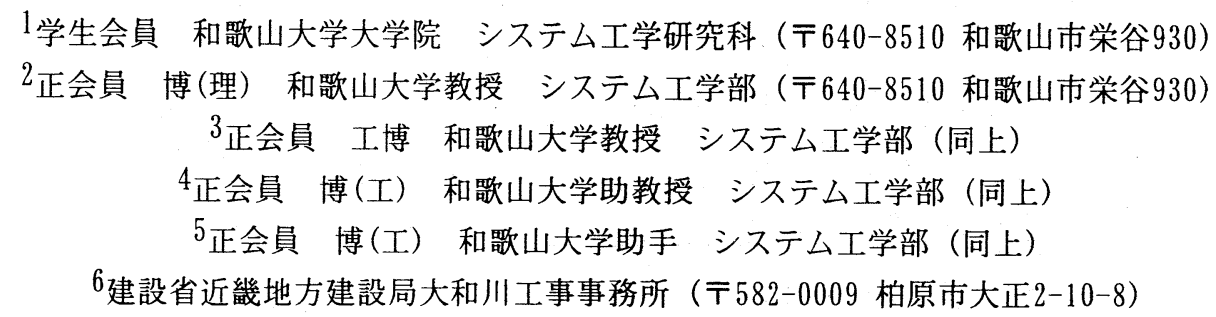

The flux of $\mathrm{NO}_{3}{ }^{-}$and $\mathrm{BOD}$ values in the Yamato river water directly increased with precipitation. Therefore, the $\mathrm{NO}_{3}{ }^{-}$was considered to originate mainly from fertilizer(A) because it was reported that the flux of $\mathrm{NO}_{3}$ in farmland drainage increased with precipitation, although domestic sewage(B) also contains a lot of $\mathrm{NO}_{3}{ }^{-}$. As sediments in the river channels and drains containing organic compounds migrated on rainy days, river $\mathrm{BOD}$ values are considered to increase after rain. On the other hand, $\mathrm{NO}_{3}{ }^{-}$ origins in branch rivers of the Yamato river are various combinations of $(\mathrm{A})$ and $(\mathrm{B})$. The $\mathrm{NO}_{3}{ }^{-}$origins of branch rivers were determined by whether the flux of $\mathrm{NO}_{3}{ }^{-}$increased with the flow rate or not. On the other hand, $\mathrm{Cl}^{-}$concentration in the Yamato river water is considered to strongly depend on the amount of domestic sewage. Although the flow rate in the river changed remarkably due to heavy rains, the flux of $\mathrm{Cl}^{-}$remained unchanged because the volume of domestic sewage did not change even on a rainy day.

Key Words : $\mathrm{Cl}, \mathrm{NO}_{3}^{-}, \mathrm{BOD}$, flow rate, land use, rain

\section{1.はじめに}

近年，河川や池・湖沼，海洋などの水域における水質 污濁が問題となっている. 水域の水質污濁は，水道用水 の取水の支障，工業用水や農業用水への利水障害，生態 系の破壊，親水空間としての価值の損失など，様々な問 題を引き起こし, 貴重な水資源の価值を大幅に低下させ るとともに, 人の健康や生活環境にも, さまざまな悪影 響を与える. その中で, 河川の水質污濁においては, 流 域内の都市化に伴う生活排水や工場排水などの污水の流 入量の増加や下水道整備の遅れなどが大きな要因となっ ている. 本研究の調査地域である大和川についても, 都 市化に伴う生活排水や工場排水の増加, 下水道整備の遅 れによる河川水の水質污濁が問題となっている. 大和川 の水質は, 昭和 30 年代後半以降の急激な都市化に伴い悪 化し, 昭和 40 年代に最も悪化し，BOD75\%值で約 $20 \mathrm{mg} / 1$ であった. 最近では $10 \mathrm{mg} / 1$ 前後になっているりものの,
全国の一級河川（109水系）のなかで，BOD值において， ワースト2位 (平成9年度) である. そのため, 水質改善 が緊急の課題となっている. その水質改善対策として, 平成6年11月に「大和川清流ルネッサンス21」が策定され， 水質改善のために, 水質浄化施設の建設や下水道整備, 河川愛護活動など，様々な施策が行なわれている12)。 た, 本研究以前に, 支川の石川において, 土地利用と水 質の関係勇や河川水と地下水の起源”について研究がなさ れている.これらの背景をふまえ, 本研究では, さらに 対象を拡大し, 大和川全流域を対象に, 大和川流域の水 質改善対策のための一資料とすべく, 現在の大和川流域 における河川水の水質特性を把握することが目的である.

\section{2. 調查対象流域概要}

調査対象流域図を土地利用分布とともに図一1に示す. 


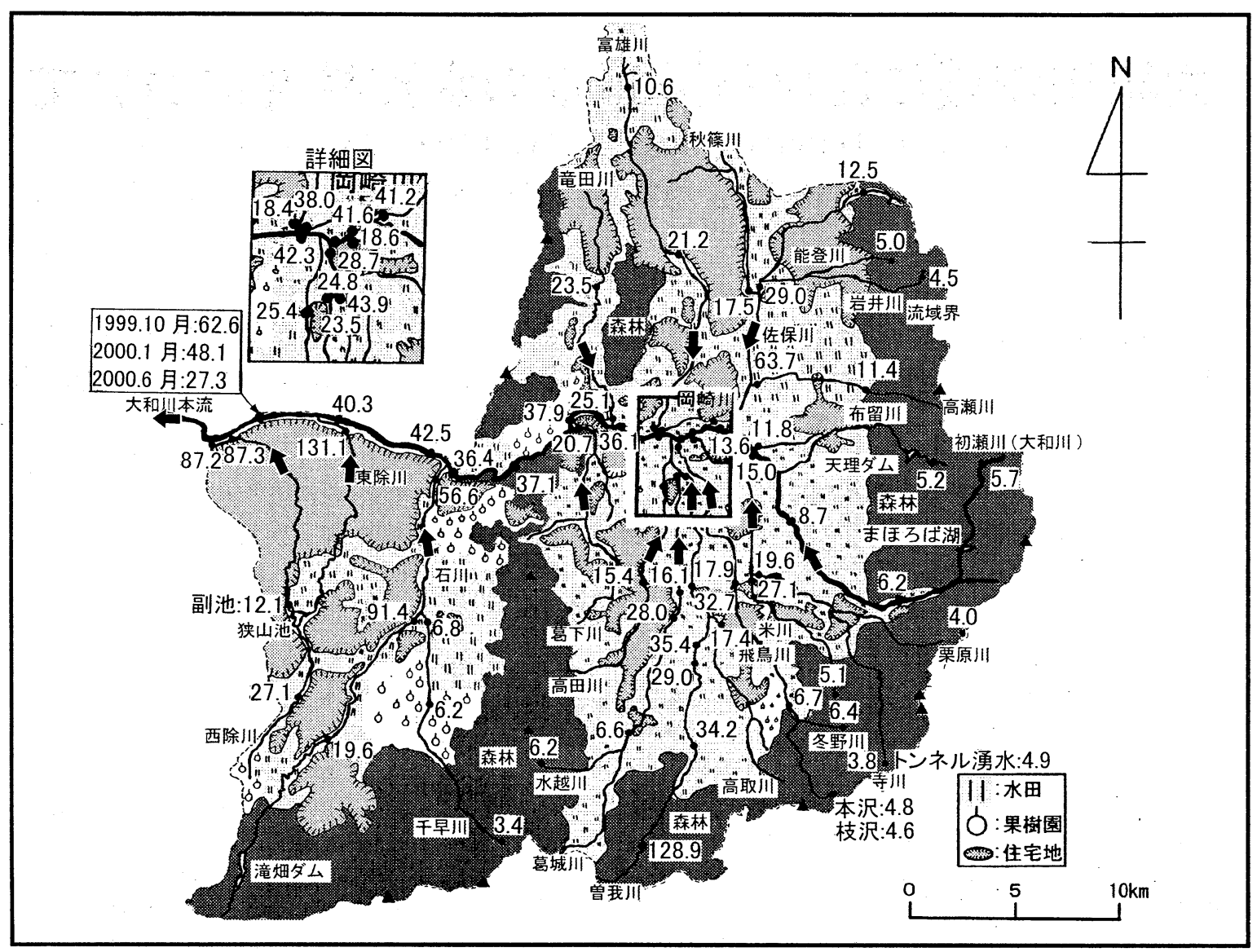

図-1 調査対象流域図(数字は1999年10月の塩素イオン濃度(mg/l), 矢印は河川の流下方向を示す).

図中の佐保川，寺川，飛鳥川，曾我川，岡崎川，富雄川 が大和川本流へ流入する部分は，採水地点が密になるた めその部分は図面の左上部に詳細図を示す．大和川は淀 川と紀ノ川の間に位置する近畿中央の一級河川で, 奈良 県西部の笠置山地に源を発し, 初瀬川渓谷を北西に流れ, 途中, 奈良県の大和平野で大小いくつかの支川と合流し ながら西へ流下し，生鴚山地と金剛山地の切れ問で「亀 の瀬」と呼ばれる渓谷部を経て大阪平野に入り，和泉山 地を源とする石川と合流し, さらに西へ流下して東除川, 西除川と合流し，大阪湾へと注ぐ一級河川である．年間 降水量約 $1400 \mathrm{~mm}$, 幹川流路延長約 $68 \mathrm{~km}$, 流域面積は約 1070 $\mathrm{km}^{2}$ で奈良県, 南大阪地域の主要河川である. 調査 対象流域の土地利用分布は, 流域の東部から南部の河川 の最上流部においては森林が分布している. 奈良県側の 大和平野においては, 水田と住宅地が分布し, 大和川本 流より南側に位置する河川の流域においては，中流部で 住宅地が密集しており, 大和川本流より北側の河川の流 域においては上流から下流にかけて住宅地が分布してい る. 大阪平野においては, 石川流域の中流から下流の東 側において，水田や果樹園が広く分布するが，石川流域 の中流から下流の西側および東除川流域，西除川流域に おいてはほとんどが住宅地である.

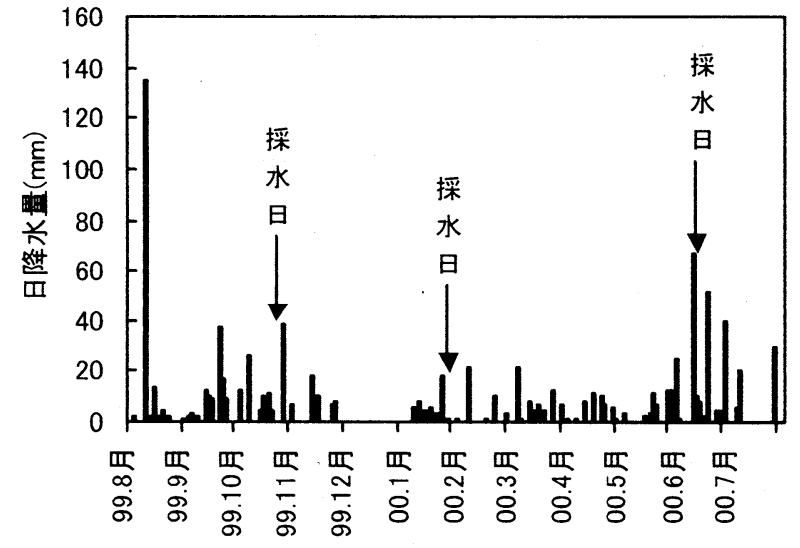

図-2 王寺雨量観測所における日降水量.

\section{3. 調査および分析方法}

調査は，大和川全流域を対象に，1999年10月25～26日， 2000 年1月24〜 25 日， 6月 12〜 13日の日程で計3回行なつ た. 図ー2に1999年8月〜2000年7月までの日降水量の変 化を示す. 図一2示すように，2000年1月24～25日，6月 12〜13日の調査は, 調査直前に降雨があった. 1999年10 月25２6日の調査においては，晴天で降雨の影響はな かった. 調査地点数は1999年10月25〜26日で70地点, 2000 年1月 $24 \sim 25$ 日で 69 地点, 2000 年6月 $12 \sim 13$ 日では6 2 


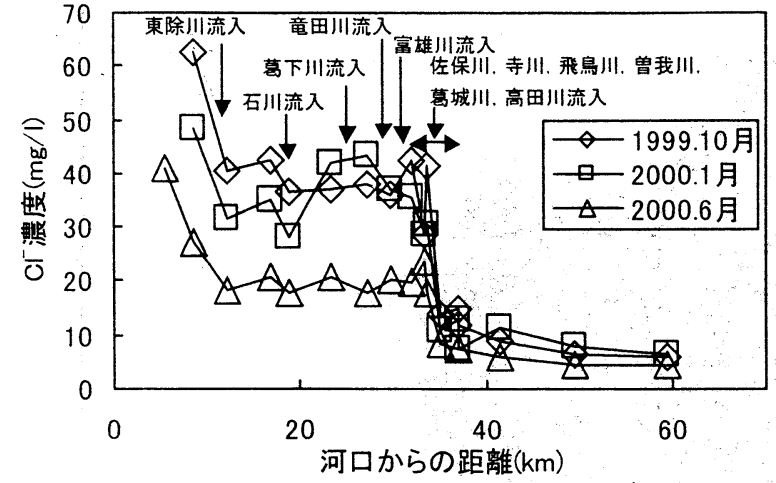

図-3 大和川本流の河口からの距離と塩素イオン濃度の関係.

地点である. 現地調査においては，一般水質分析用に採 水を行ない, さらに, 全調査地点のうち, 26ヶ所では, 建設省「河川砂防技術基準(案)」に従う方法で, 流量観測 も行なった. 現地調査で採水したサンプルは分析を行な うまで冷暗所に保管した. また，サンプルは分析を行な うまでに, 孔径 $0.45 \mu \mathrm{m}$ のメンブランフィルターで滤過 を行なった. サンプルの分析は, ナトリウムイオン, カ ルシウムイオン, 塩素イオン, 硝酸イオン, 硫酸イオン, リン酸イオンは, イオンクロマトグラフィーで, 重炭酸 イオンは滴定で行なった. 有機污濁の指標となるBODは, 最も標準的な方法(JIS K0102 21および32.3)で測定した.

\section{4. 水質分析結果と考察}

\section{(1)塩素イオン濃度の流域内分布}

図ー1に1999年10月の流域内における塩素イオン濃度 の分布を示す. 最上流部の森林部では濃度が低く, 住宅 地が分布する部分を通過すると塩素イオン濃度は上昇す る. これは住宅地からの生活排水の流入が原因であると 考えられる. 流域上流部でも, 佐保川中流や曽我川上流 のように，一部高い塩素イオン濃度を示す地点があるが, 全体的にみて流下に伴い塩素イオン濃度は上昇する傾向 にある. 流域上流部で塩素イオン濃度が高い曽我川上流 と佐保川中流の地点の原因は, 兽我川上流の地点につい ては, この地点より上流に団地がみられたことから, 団 地からの排水が原因と考えられる. 佐保川中流の地点に ついては周囲に工場群が存在したため, そこからの排水 の流入が原因と考えられる. また，2000年1月，6月の分 布についても, 1999年10月と同様の変化を示した.

\section{（2）大和川本流の塩素イオン濃度の変化}

大和川流域は多くの支川が存在し，それらの支川が大 和川本流の塩素イオン濃度にどのような影響を与えてい るかをみるため, 大和川本流の地点の河口からの距離と 塩素イオン濃度の関係を調べた. 大和川本流の地点の河 口からの距離と塩素イオン濃度の関係を図一3に示す.

図ー1，3から前項で述べたように，流下に伴い塩素イ

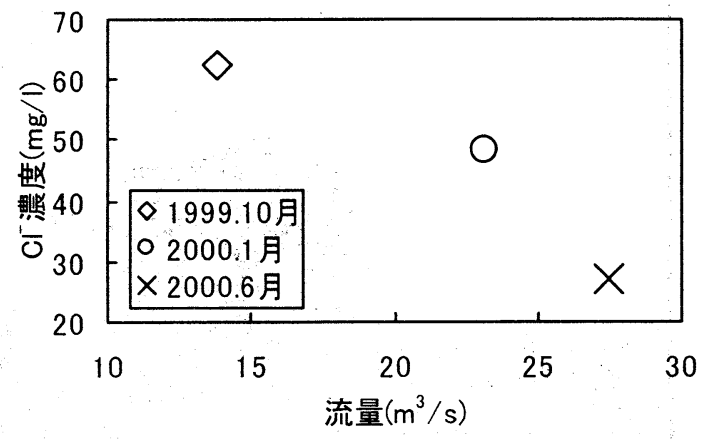

図-4 本流下流部の流量と塩素イオン濃度の関係.

オン濃度が上昇しており, 様々な支川の流入により塩素 イオン濃度が上昇することがわかる. また，河口からの 距離が30〜35km付近で塩素イオン濃度が大きく上昇し ている.この原因としては，河口からの距離が30〜 $35 \mathrm{~km}$ 付近は, 住宅地が多く存在することによって塩素 イオン濃度が大和川本流より高くなった佐保川, 寺川, 飛鳥川, 曽我川, 葛城川, 高田川が合流する部分で, そ れらの多くの支川がまとまって流入するためと考えられ る. 特に, その支川のなかでも, 図一1から, 佐保川, 兽我川から流入する河川水の塩素イオン濃度が高いこと から, 佐保川, 曽我川からの河川水の流入が大和川本流 の塩素イオン濃度の上昇に大きく影響していると考えら れる. また, 佐保川, 兽我川からの河川水の塩素个オン 濃度が高い原因として, 佐保川中流, 兽我川上流の塩素 イオン濃度が比較的高い地点の河川水が影響しているこ とが考えられる.

\section{(3) 大和川本流の塩素イオン濃度の季節変化}

流域全体としての季節変化をみるため, 大和川本流下 流部の西除川合流前の地点での塩素イオン濃度を流域全 体の代表値とした. その地点での塩素イオン濃度と流量 の関係を図一4に示す. 図一4から, 流量の増加ととも に塩素イオン濃度は減少していることがわかる. また, 2000年1月，6月の調査時には降雨があった. これらのこ とから, 大和川本流の最下流の地点における塩素イオン 濃度の季節変化は降雨による希釈の影響だと考えられる. また, 他の地点の季節变化は, 代表として, 図一3に示 す大和川本流の地点の塩素イオン濃度を比較すると, 下 流部(約 $20 \mathrm{~km}$ 以下)では, 降雨直後の雨水による希釈がみ られるが, 上流部(35km以上)では塩素イオン濃度はあま り変わらない.

\section{(4) 硝酸イオン濃度の流域内分布と季節変化}

図一5に，1999年10月の流域内における硝酸イオン濃 度の分布を示す. 図一5から, 全体的にみて, 流下によ る硝酸イオン濃度の変化は一様ではない. また, 流域上 流部において, 曽我川上流や佐保川中流の地点では, 塩 素イオン同様, 比較的高い濃度を示し，この他にも，葛 城川支流の水越川上流も高い硝酸イオン濃度を示した. 


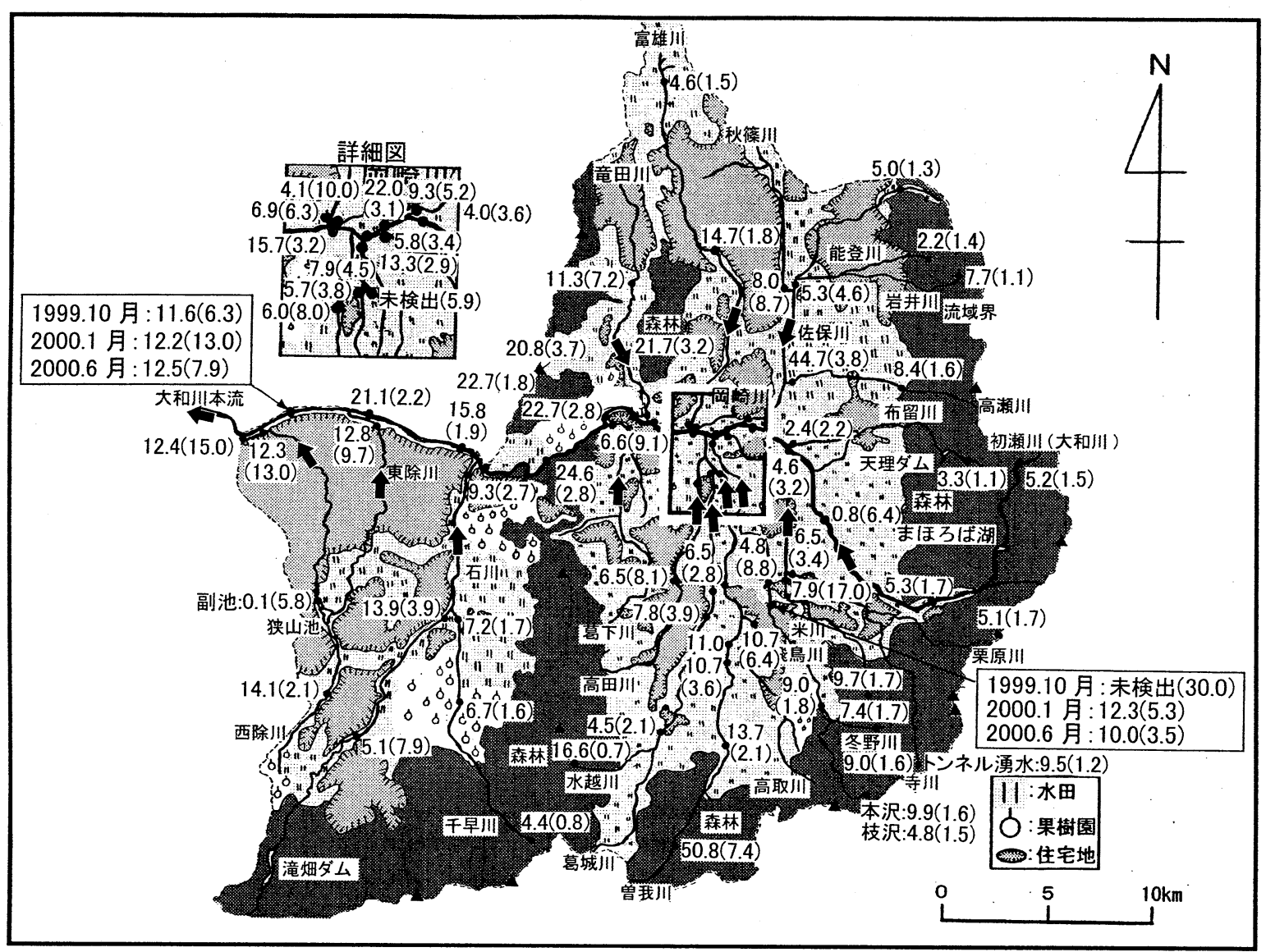

図－5 1999年10月の硝酸イオン濃度 $(\mathrm{mg} / \mathrm{l})$ の流域内分布(カッコ内数字はBOD (mg/l), 矢印は河川の流下方向を示寸).

この原因としては，塩素イオン同様，兽我川上流につい ては団地の影響だと考えられるが，佐保川中流，水越川 上流については現段階では原因は不明である．また， 2000年1月，6月の分布についても，全体的に，1999年10 月と同様の変化を示した.

流域全体としての季節変化をみるため, 大和川本流下 流部の西除川合流前の地点の硝酸イオン濃度を流域全体 の代表値とした．その地点での硝酸イオン濃度の季節変 化をみると， 1999 年 10 月で $11.6 \mathrm{mg} / \mathrm{l} ， 2000$ 年 1 月で $12.2 \mathrm{mg} / \mathrm{l}, 2000$ 年6月で $12.5 \mathrm{mg} / \mathrm{l}$ と，どの月もほぼ同じ濃 度を示し, 明瞭な季節変化は見られない. 他の地点にお いては，流域最上流部の森林部では，兽我川上流を除い て，明瞭な季節変化はみられず，その他の地点は，地点 ごとに季節変化は異なった。

\section{(5) BODの流域内分布と季節变化}

図一5に1999年10月の流域内におけるBODの分布を示 す. 図一5から, 流域上流部の森林部では, 曽我川上流 の地点を除いて低い值を示す．そして，水田や果樹園と いった農地や住宅地を通過すると濃度は上昇する。この 原因としては農地や住宅地からの有機物を含んだ排水の 流入が考えられる．また，1999年10月において，曽我川 中流でBODが $30 \mathrm{mg} / \mathrm{l}$ 極端に高い值を示す地点がある. この原因としては光合成の影響が考えられる，一般的に 藻類などのプランクトンによる光合成の反応式は次式で
表されるう。.

$$
\begin{gathered}
106 \mathrm{CO}_{2}+16 \mathrm{NO}_{3}{ }^{-}+16 \mathrm{H}^{+}+\mathrm{H}_{3} \mathrm{PO}_{4}+122 \mathrm{H}_{2} \mathrm{O} \\
=\left(\mathrm{CH}_{2} \mathrm{O}\right)_{106}\left(\mathrm{NH}_{3}\right)_{16}\left(\mathrm{H}_{3} \mathrm{PO}_{4}\right)+138 \mathrm{O}_{2}
\end{gathered}
$$

(1)式から光合成においては硝酸イオンが必要なことから, 図一5より，BODが30mg/lを示した曽我川中流の地点の 硝酸イオン濃度をみると, 上流では $50.8 \mathrm{mg} / 1$ であった硝 酸イオン濃度は, 検出されないぐらいまで減少している ことがわかる. 逆にBODは上流の $7.4 \mathrm{mg} / 1$ から $30.0 \mathrm{mg} / 1$ に 増加している. また，(1)式の反応において，光合成には リン酸 $\left(\mathrm{H}_{3} \mathrm{PO}_{4}\right)$ も必要なことから, リン酸イオンも測定 したが，1999年10月のこの地点においては，リン酸イオ ンは検出されなかった. さらに, 曽我川流域にはいくつ か堰が存在し，この堰によって水が堰き止められ，河川 水の流れがほとんどない状態になった部分が多くみられ， この曽我川中流の地点も水の流れが止まったような状態 になっていた，そのため, 光合成がより起こり易い状況 になっていたことも考えられる.これらのことから，曽 我川中流の地点でBODが $30.0 \mathrm{mg} / \mathrm{l}$ とかなり高い值を示し た原因は，上流から高濃度の硝酸イオンが流入し，堰に よって河川水の流れがほとんどなくなったことにより， 硝酸イオンが検出されないぐらいまで光合成が十分に行 なわれたためだと考えられる. 次に，この地点における 2000 年1月のBODと硝酸イオン濃度をみると, BODは 
5.3mg/lで1999年10月にくらべ大きく減少している．ま た，硝酸イオン濃度は逆に $12.3 \mathrm{mg} / \mathrm{l}$ と大きく増加し，リ ン酸イオンも $0.1 \mathrm{mg} / \mathrm{l}$ と検出された. さらに, 2000 年1月 の調査は前日まで降雨があったため, この地点の河川水 に流れがあった:このことから，2000年1月はこの地点 において流れがあったため, 光合成は起こらず, 光合成 に必要な物質や有機物は流されていることが考えられる. また，2000年1月にこの地点でリン酸イオンが検出され たのも光合成により使用されず，残ったためと考えられ る. 2000 年 6 月は, BODが $3.5 \mathrm{mg} / \mathrm{l}$, 硝酸イオン濃度が $10.0 \mathrm{mg} / 1$ と2000年1月にくらべいずれも減少している. これは, 調查前一週間の降雨量が $120 \mathrm{~mm}(\text { 葛城 })^{6}$ と大量の 降雨があったことから, 降雨による希釈が考えられる. また，2000年1月，6月の分布については，全体的に, 1999年10月と同様の変化を示した.

流域内の季節変化は, 塩素イオン, 硝酸イオンと同様 に, 大和川本流下流部の西除川合流前の地点のBODを流 域全体の代表值とした. その地点でのBODの季節変化を みると, 1999年10月は6.3mg/l, 2000年1月は $13.0 \mathrm{mg} / \mathrm{l}$, 2000年6月は7.9mg/1で2000年1月のBODが最も高い. 他 の地点に扩いては, 流域最上流部の森林部では, 兽我川 上流を除いては, 明瞭な季節変化はみられなかったが, その他の地点は, 地点によって季節変化は異なった.

\section{（6）大和川流域からの物質の流出負荷量の季節変化}

大和川流域からの塩素イオン, 硝酸イオン, ナトリウ ムイオン, カルシウムイオン, 重炭酸イオン, 硫酸イオ ン, BODの流出負荷量の季節変化から, それらの物質が ぞの発生源の影響を強く受けているかについて考察した. 表一 1 に, 各物質の流域全体からの流量と月当たりの流 出負荷量を示す. 表一1の流出負荷量は, 大和川本流下 流部の西除川流入前の地点を流域全体の代表地点とし, そこで得られた上記の物質の水質データと流量を乗じ， 月当たりの量に換算して算定した. 表一1のカッコ内は, 各物質と流量の1999年10月の值に対する增加率を示す.

これらの結果から, 塩素イオンの負荷量は; 流量が増 加してもほとんど変化しない. 住宅地からの生活排水は 季節や時間によりある程度は変動するが, 住宅地の面積 が大きく増加しなければ生活排水も大きく増加しないと 考えられる. また, 塩素イオンが住宅地の影響を強く受 けるなら, 降水により流量が増加しても, 塩素イオン量 は増加せず，排出量は一定であると考えられる．このこ とから, 塩素イオンの負荷量は, 生活排水の影響を強く 受けていると考えられる.

次に，硝酸イオン量は1999年10月，2000年1月，6月の 順に増加し, 流量の増加に伴い硝酸イオンの流出負荷量 も増加していることがわかる. また，2000年1月，6月の 硝酸イオンの増加率は流量の増加率とほぼ一致する. 流 量が増加すると硝酸イオン量が増加する原因として, 土 壌中の硝酸イオンが流出したと考えられる．2000年1月
表-1 大和川本流下流地点の物質負荷量と流量

.(カッコ内数字は1999年10月に対する増加率).

\begin{tabular}{|l|c|c|c|}
\hline & 1999.10 月 & 2000.1 月 & 2000.6 月 \\
\hline $\mathrm{Cl}^{-}(\mathrm{t} /$ month $)$ & $2317(1.00)$ & $2993(1.29)$ & $1943(0.84)$ \\
\hline $\mathrm{NO}_{3}{ }^{-}(\mathrm{t} /$ month $)$ & $429(1.00)$ & $759(1.77)$ & $889(2.07)$ \\
\hline $\mathrm{BOD} \mathrm{t} /$ month $)$ & $233(1.00)$ & $808(3.47)$ & $563(2.42)$ \\
\hline $\mathrm{Na}^{+}(\mathrm{t} /$ month $)$ & $1844(1.00)$ & $2168(1.18)$ & $1610(0.87)$ \\
\hline $\mathrm{Ca}^{2+}(\mathrm{t} /$ month $)$ & $1143(1.00)$ & $1551(1.36)$ & $1902(1.66)$ \\
\hline $\mathrm{HCO}_{3}{ }^{-}(\mathrm{t} /$ month $)$ & $4299(1.00)$ & $5593(1.30)$ & $5510(1.28)$ \\
\hline $\mathrm{SO}_{4}{ }^{2-}(\mathrm{t} /$ month $)$ & $1220(1.00)$ & $1571(1.29)$ & $1721(1.41)$ \\
\hline 流量 $\left.^{3} \mathrm{~m}^{3} / \mathrm{s}\right)$ & $13.83(1.00)$ & $23.21(1.68)$ & $27.50(1.99)$ \\
\hline
\end{tabular}

と6月の調査時には降雨があった，降雨時には，農耕地 や山地から土壌層中に存在する硝酸イオンが流出するこ とが知られている7).よって, 硝酸イオンの負荷量は農 地からの流出水の影響を強く受けていると考えられる.

BODの流出負荷量については，1999年10月に比べ2000 年1月は急増し，2000年6月は2000年1月に比べると少な くなっているが1999年10月に比べるとBODの流出負荷量 は大きい．また，先にも述べたように，2000年1月は調 查前日まで，6月は調査初日まで降雨があった，そのた め, 表-1より, 流量も1999年10月に比べ, 2000年1月, 6月は大幅に増加している. 降雨時には, 流量增加によ り水路や河道内に貯留, 堆積した物質を運搬し, 懸濁態 物質が流出することが知られている7)。よって，これら のことから, BOD量の変化は, 住宅地や農地からの排水 だけでなく, 河道や水路に貯留・堆積する有機物の流出 の有無も影響することが考えられる.

ナトリウムイオン, 重炭酸イオンは, 流出負荷量の変 化や増加率の変化が, 流量の増加に対して大きくなく, 塩素イオンと同様の変化を示すことから, 住宅地からの 生活排水の影響を強く受けていると考えられる. カルシ ウムイオン, 硫酸イオンは, 流量の増加とともにそれぞ れの物質量と増加率が増加し, また, 畑地・水田には, 施肥される肥料中に硫黄が含まれ，そして，土壌の酸性 化の中和剂として石灰などが施用されるため, 農地から の排水には硫酸イオンやカルシウムイオンが含まれてい ることが知られている8).このことは, 石川流域でも確 認されている3).これらのことから, 硫酸イオン, カル シウムイオンは農地からの流出水の影響を強く受けてい ると考えられる.

\section{（7）大和川流域の支川の水質特性}

大和川流域の各支川の水質特性を把握するため, 図一 6に各支川末端の地点の, 流量の増加率に対する硝酸イ オン量の増加率を示す. 流量, 硝酸イオン量の増加率は, すべて1999年10月の值に対するものである. しかし, 曽 我川の硝酸イオン量の増加率は, 曽我川末端の地点の 1999年10月の硝酸イオンが未検出であったため，2000年 1月に対する増加率とした. 東除川のデータは流量を測 


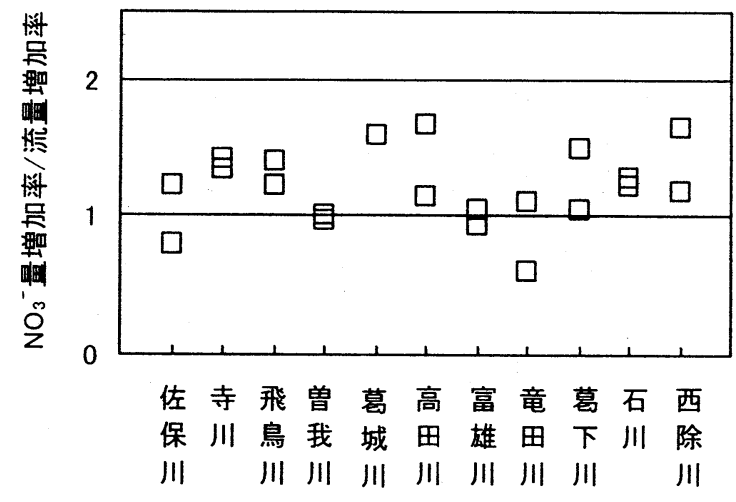

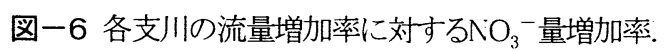

定していないため掲載していない，流量の増加率に対す る硝酸イオン量の増加率は, 基本的に, 生活排水の影響 を強く受けていると, 1よりも小さくなり, 農地からの 流出水の影響を強く受けていると，1以上になると考え ることができる.

図一6から, 佐保川, 富雄川, 竜田川は, 流量の増加 率に対する硝酸イオン量の増加率が 1 を越える点もある が，全体的に值は低い. また，これらの流域は図一1に 示すように住宅地が多い.よって，これらのことから， 佐保川, 富雄川, 竜田川は生活排水の影響の強い流域で あると考えられる。

寺川, 飛鳥川, 葛城川, 高田川, 葛下川, 石川は, 流 量の増加率に対する硝酸イオン量の増加率が 1 以上であ る. 曾我川は, 2000年1月に対する割合をとっているた め，值は1を示すが，2000年6月の值もほぼ1であるため, 流量の増加により硝酸イオンは増加していると考えられ る. また，これらの河川の流域には農地が多く分布する. これらのことから, 寺川, 飛鳥川, 葛城川, 高田川, 葛 下川, 石川, 曾我川は農地からの流出水の影響が強い流 域であると考えられる.

しかしながら, 西除川は, 流量の増加率に対する硝酸 イオン量の増加率が比較的高いが，これらの流域は住宅 地が多く分布し，必ずしもこの指標が土地利用と一致し ていなかった．この原因として，西除川は住宅地が多く 分布する都市河川であることから，降雨時までに生活排 水などにより河道内に堆積した有機堆積物が，降雨時に 流出したことが考えられる.

最後に，本研究の結論として，(1)〜(7)項の結果から， 広い流域の河川水の水質の変化をみる場合においては, 濃度だけでなく, 流量と物質の流出負荷量の変化も考慮 する必要があると考えられる。

\section{5. まとめ}

大和川流域の塩素イオン濃度は，住宅地が分布すると
ころで高かったため, 生活排水の流入が考えられた. ま た, 塩素イオンの流出負荷量は, 降雨により流量が増加 しても, 大きく変化しなかった. この原因として, 降雨 により流量か増加しても生活排水の流入量は大きく変化 しないためと考えられた. しかし, 硝酸イオンの流出負 荷量は, 流量とともに増加した.この原因として, 降雨 時には, 農耕地や山地から土壌層中に存在する硝酸イ才 ンが流出することが知られていることから, 農地からの 流出水の影響を強く受ける物質であると考えられた. B ODの流出負荷量も降雨時に増加し, 降雨時には, 流量 増加により水路や河道内に貯留, 堆積した有機物のよう な懸濁態物質が流出することが知られているため, 生活 排水や農地からの流出水以外にも, 河道や水路に貯留・ 堆積する物質も影響することが考えられた. 大和川流域 の支川の硝酸イオンの起源は, 硝酸イオンの流出負荷量 が流量とともに増加するかしないかによって推定され, その結果，起源は支川によってさまざまだった.

まとめとして，広い流域の河川水の水質の変化をみる 場合においては, 濃度だけでなく, 流量と物質の流出負 荷量の変化も考慮する必要があると考えられた.

\section{参考文献}

1) 大和川清流ルネッサンス21協議会 : 大和川水系水睘境改善 緊急行動計画(清流ルネッサンス21), 1994.

2) 大和川清流ルネッサンス21協議会 : 水環境改善緊急行動計 画 大和川清流ルネッサンス 21.

3) 平田健正 - 井伊博行 - 長谷部正彦 - 江種伸之 - 坂本康 - 条 川高徳・西山幸治・酒井信行・岩崎宏和 : 土地利用特性の 河川水質に及ぼす影響一大阪府石川流域一, 土木学会論文 集, No.614/II -46, pp. 97-107, 1999.

4）井伊博行 - 平田健正 - 長谷部正彦 - 江種伸之 - 坂本康 - 条 川高徳・西山幸治・酒井信行 - 堀井壮夫 : 環境同位体及び 化学組成からみた石川流域の河川水之地下水の起源につい $\tau$, 水工学論文集, 第43巻, pp. 205-210, 1999.

5) 井伊博行 - 平田健正・松尾宏-田瀬則雄-西川雅高 : 茶畑 周辺の池水中の $\mathrm{pH}$ 変化之窒素、リン、硫黄、アルミニウム の挙動について, 土木学会論文集, No.594/VII-7, pp. 57 $-63,1998$.

6) 建設省大和川工事事務所 : 大和川流域葛城地点雨量デー夕, 2000.6月.

7）国松孝男・村岡浩爾 編著 : 河川污濁のモデル解析, 技報 堂出版, 1989.

8) 井伊博行 - 平田健正 - 松尾宏・田瀬則雄・西川雅高 : 茶畑 施肥に由来する硝酸性窒素と周辺表流水に及ぼす影響, 水 工学論文集, 第41巻, pp. 575-580, 1997. 